\title{
Tribal Medicinal Plants Specifically Of Rajasthan
}

\author{
Dr. Tripti Yadav ${ }^{1} \mid$ Dr. Ashish Kumar Mangal Bhai Patel ${ }^{2} \mid$ Dr. Shefali Jain ${ }^{3}$ \\ ${ }^{1}$ Asst Professor, Dept of Botany, SS Jain Subodh College of Global Excellence, Sitapura, Jaipur. \\ ${ }^{2}$ Research Scholar, Dept of Botany, Rajasthan University, Jaipur. \\ ${ }^{3}$ Asst Professor, Dept of Botany, SS Jain Subodh College of Global Excellence, Sitapura, Jaipur.
}

\section{To Cite this Article}

Dr. Tripti Yadav, Dr. Ashish Kumar Mangal Bhai Patel and Dr. Shefali Jain, "Tribal Medicinal Plants Specifically Of Rajasthan", International Journal for Modern Trends in Science and Technology, Vol. 06, Issue 07, July 2020, pp.:140-142; https://doi.org/10.46501/IJMTST060722

\section{Article Info}

Received on 13-June-2020, Revised on 29-June-2020, Accepted on 18-July-2020, Published on 23-July-2020.

\section{ABSTRACT}

Around seven percent of tribal population of India lives in Rajasthan. Ethnobotany can be defined as the total natural and traditional relationship and the interactions between man and his surrounding plant wealth from times immemorial, due to sheer, necessity, intuition, observation and experimentation. Ethnobotany of India might is among the earliest in the world and all traditional systems of medicine had their roots in ethnobotany. Rajasthan has rich cultural diversity and biodiversity. The world health organization (WHO) has recently recognized the importance of traditional medicinal system in different parts of globe and around 4000 plant spp. have been identified which are used in traditional herbal medicinal system. However, proper identification of these crude drugs in Botanical terms has not been carried out or still remains disputed as different authors ascribed different plants source to various crude drugs (Sanghi and Kumar, 2000). More over several difficult diseases have problem related with vitality, diabetes, memory loss, could be cured effectively by use of herbal medicine, which is generally not possible by the Allopathic medicines. However, there is no systematic documentation of this information. Medicinal plants are distributed across diverse habitats and landscape. Around 70 per cent of India's medicinal plants are found in tropical areas. Mostly in the various forest types spread across the Western and Eastern ghats, the Vindyas, Chota Nagpur Plateau, Aravallis and Himalayas.

KEY WORDS: ethnobotany, tribes, botanical, plants, habitats, WHO

Copyright (C) 2020 International Journal for Modern Trends in Science and Technology DOI: https://doi.org/10.46501/IJMTST060722

\section{INTRODUCTION}

Tribal people and ethnic races throughout the world have developed their own culture, costumes, medicinal practices, etc. A large number of wild and cultivated plants are being used by them for the treatment of various elements, thus, a considerable amount of information on medicinal plants is available with these communities. Rajasthan is one of the largest states located in the Northwestern part of India. Geographically, it lies between $23^{\circ} 3^{\prime}$ to $30^{\circ} 12^{\prime}$ longitudes and $69^{\circ} 30^{\prime}$ to $78^{\circ} 17^{\prime}$ latitudes. Southern part of Rajasthan comprising Banswara, Chittorgarh, Dungarpur and Udaipur districts is the tribal belt in which Bhil, Damor, Garasia, Kalbelia,Kathodia and Meena are the main tribes. The plants growing around them form an integral part of their culture. These people are largely dependant on their traditional healing system for their healthcare and the information is passed on from generation to generation through the word of mouth. $(1,2)$

The climate is tropical with the maximum temperature ranging between 
$38.3^{\circ}-46.0^{\circ} \mathrm{C}$ (during summer) and the minimum between $7.0^{\circ}-11.6^{\circ} \mathrm{C}$ (during winter). Average annual rainfall has been recorded to be $65.03 \mathrm{~cm}$. The area is characterized by the tropical deciduous type of vegetation consisting of Anogeissus latifolia (Roxb. ex DC.) Wall. ex Guill \& Perr., Anogeissus pendula Edgew, Balanites aegyptiaca (Linn.) Delile., Boswellia serrata Roxb., Diospyros melanoxylon Roxb., Madhuca indica J.F. Gmelin, Tectona grandis Linn. f., Terminalia arjuna (Roxb. ex DC.) Wight \& Arn., etc. as the important plant species. Significant contribution has been made by several workers on the ethnobotany in India ${ }^{1-6}$. In Rajasthan, these studies have been carried out from different parts of the state ${ }^{7-15}$. However, the studies on the ethnomedicinal plants of southern Rajasthan are scantier ${ }^{16}$. Therefore, an attempt has been made here to collect the information about plants used by tribals in their traditional healthcare system. The study is based on interviews with local tribals living in the region and entirely dependent on the plants occurring around them. $(1,3)$

\section{AIMS AND OBJECTIVES}

1. To study about medicinal plants utilized by tribal population of Rajasthan

2.To discuss utility medicinal plants in ayurveda

3. To study significance and scope of ethnobotany

\section{MATERIALS AND METHODS}

Field trips are conducted with the local medicine men. Generally tribals, who know about the herbal medicine, do not want to give all the information because they believe that when the medicinal plant is disclosed its medicinal properties will be lost. The people, who can provide information about medicinal plants, were consulted. For authenticity about medicinal properties of plants, the information collected during fieldwork was verified at different places through different informants and in different seasons.(3) Each of the plant species collected with the help of the informants have been recorded, photographed and identified. (4)

\section{OBSERVATIONS}

\begin{tabular}{|l|l|}
\hline Plant name/Family & Local name \\
\hline Abrus precatorius L. Papilionaceae & Chirmu Ratti \\
\hline Acacia catechu (L.f.) Willd. & Khair katha \\
Mimosaceae & \\
\hline $\begin{array}{l}\text { Acacia nilotica (L.) Willd. ex Del } \\
\text { Mimosaceae }\end{array}$ & Boriyo \\
\hline
\end{tabular}

Acanthospermum hispidum DC.

Dokanta

Asteraceae

Achyranthes aspera L.

Amaranthaceae

Aegle marmelos (L.) Corr.

Andhi Jhara

Rutaceae

Anogeissus latifolia (Roxb. ex DC.) Wall.Dhawari

ex Guill \& Perr. Combretaceae

Barleria prionitis L. Acanthaceae

Danteli, Kala bans

Butea monosperma (Lam.) Taubert. Khankra,

Papilionaceae

Sura

Calotropis procera (Ait) R. Br.

Asclepiadaceae

Capparis decidua (Forsk.) Edgew.

Capparaceae

Chlorophytum tuberosum (Roxb.)

Baker Liliaceae

Curculigo orchioides Gaertn.

Hypoxidaceae

Dichrostachys cinerea (L.) Wight \& Arn. Goya-hair

Mimosaceae

kolai

Echinops echinatus Roxb. Asteraceae Oont Kantilo

Enicostema axillare (Lam.) Roynal $\quad$ Nami

Gentianaceae

Euphorbia caducifolia Haines

Danda Thore

Euphorbiaceae

Ficus benghalensis L.

Moraceae

Plant name/Family

Bar, Bargad

Helicteres isora $\mathrm{L}$.

Local name

Sterculiaceae

Anteri, Maro

Holoptelea integrifolia (Roxb.) Planch

Ulmaceae

\begin{tabular}{ll}
\hline Jatropha curcas L. Euphorbiaceae & Ratan Jot
\end{tabular}

\begin{tabular}{l|l}
\hline Madhuca indica J.F. Gmelin & Mori
\end{tabular}

Sapotaceae

$\begin{array}{ll}\text { Medicago sativa L. Papilionaceae } & \text { Rizka }\end{array}$

Peristrophe paniculata (Forsk.) Burm. Bhamwara

Acanthaceae

Kakar

Ricinus communis L. Euphorbiaceae Arandi

\begin{tabular}{l|l}
\hline Solanum surattense Burm. f. & Kateli,
\end{tabular}

Solanaceae

Bhurangni

\begin{tabular}{ll}
\hline Soymida febrifuga (Roxb.) A. Juss. & Rohini
\end{tabular}

Meliaceae

\begin{tabular}{|l|l}
\hline Tinospora cordifolia (L.) Miers & Giloy
\end{tabular}

Menispermaceae

Xanthium strumarium L.

Asteraceae

Ziziphus nummularia (Burm, f.) Wight Jhari, Bordi

\& Arn. Rhamnaceae 


\section{CONCLUSION}

Now a days, much of the wealth of knowledge is being lost as the traditional culture is disappearing. Hence, documentation of traditional practices of herbal medicine will be coherence in future. There is an urgent need to study and document the precious knowledge of ethnomedicinal practices. Documentation of such information will go a long way in developing new drugs through further researches. The information on the ethnomedicinal plants will certainly help in developing strategies for the conservation, cultivation of traditional medicine and economic welfare of rural and tribal population of this region of Rajasthan. The plants and the remedies as recorded here need phytochemical and pharmacological screening for their active principles and clinical trials for therapeutic action. $(6,7)$

\section{REFERENCES}

[1] "Ethnobotany". www.fs.fed.us.

[2] Biocyclopedia.com. "Ethnobotany - Biocyclopedia.com". www.eplantscience.com.

[3] Kandell, Jonathan (13 April 2001). "Richard E. Schultes, 86, Dies; Trailblazing Authority on Hallucinogenic Plants" via NYTimes.com.

[4] Kochhar, S. L. (2016). Economic Botany: A Comprehensive Study (5 ed.). Cambridge University. p. 644. ISBN 9781316675397.

[5] Soejarto, D.D. et. al. (2005): "Ethnobotany/ethnopharmacology and mass bioprospecting: Issues on intellectual property and benefit-sharing", Journal of Ethnopharmacology, V. 100, 15-22. Link to Article

[6] Soejarto, D.D.; Fong, H.H.S.; Tan, G.T.; Zhang, H.J.; Ma, C.Y.; Franzblau, S.G.; Gyllenhaal, C.; Riley, M.C.; Kadushin, M.R.; Pezzuto, J.M.; Xuan, L.T.; Hiep, N.T.; Hung, N.V.; Vu, B.M.; Loc, P.K.; Dac, L.X.; Binh, L.T.; Chien, N.Q.; Hai, N.V.; Bich, T.Q.; Cuong, N.M.; Southavong, B.; Sydara, K.; Bouamanivong, S.; Ly, H.M.; Thuy, T.V.; Rose, W.C.; Dietzman, G.R. (2005). "Ethnobotany/ethnopharmacology and mass bioprospecting: Issues on intellectual property and benefit-sharing" (PDF). Journal of Ethnopharmacology. 100 (1-2): 15-22. doi:10.1016/j.jep.2005.05.031. PMID 15993554 .

[7] White, James T. (1931). The National cyclopædia of American biography ... v.21. University of Michigan.

[8] Ponman, Bussmann, Bruce E, Rainer W. (2012). Medicinal Plants and the Legacy of Richard E. Schultes (PDF). Missouri Botanical Garden. ISBN 0984841520.

[9] Biocyclopedia.com. "Ethnobotany - Biocyclopedia.com". www.eplantscience.com. 